Indonesian Journal of Biotechnology, June, 2013

Vol. 18, No. 1, pp.64-69

\title{
The Diversity of Legume-Nodulating Bacteria from Several Agroecosystems in Sumberjaya, Lampung
}

\author{
Sri Wedhastri ${ }^{* *}$, Yuliana Prahastiwi ${ }^{1}$, Jaka Widada ${ }^{1}$, Donny Widianto ${ }^{1}$, \\ and Siti Kabirun ${ }^{1}$
}

\footnotetext{
${ }^{1}$ Department of Agricultural Microbiology, Faculty of Agriculture, Universitas Gadjah Mada, Yogyakarta, Indonesia
}

\begin{abstract}
Bacteria that capable of forming root nodules on legumes are known as Rhizobia. They have also known as Legume- Nodulating Bacteria (LNB). They can fix nitrogen from the atmosphere. Diversity of Legume-Nodulating Bacteria is affected by biotic factors (such as their genetic factors, plants, and competition with the other soil microbes) and abiotic factors (such as land use, soil's temperature, $\mathrm{pH}$, chemistry and soil's properties). The aim of this experiment is to know the diversity of eleven Legume- Nodulating Bacteria based on their phenotypic and genotypic characters. The eleven LNB used in this experiments were isolated from several agroecosystems in Sumberjaya, Lampung. The analysis of these LNB diversity were carried out by characterizing both phenotypic and genotypic properties. The diversity analysis showed that the eleven LNB isolates had high diversity, based on nodule formation, and classified into two groups of cross inoculation group.
\end{abstract}

Key words: Rhizobia, phenotypic diversity, genotypic diversity

\section{Introduction}

Bacteria that capable of forming root nodules on legumes are known as Rhizobia (Barcellos et al., 2007). They have also have known as Legume-Nodulating Bacteria (LNB) (Mahdi et al., 2011). There are currently 98 species in 13 genera of Rhizobia which include genera Rhizobium, Mesorhizobium, Ensifer, Burkholderia, Bradyrhizobium, Phyllobacterium, Microvirga, Azorhizobium, Ochrobactrum, Cupriavidus, Methyllobacterium, Devosia and Shinella (Weir, 2012).

Diversity of Rhizobia can be analyzed by characterizing their phenotypic and genotypic properties (Naz et al., 2009). Phenotypic characterization of Rhizobia can be carried out by identifying their cell's

*Corresponding author:

Sri Wedhastri

Department of Agricultural Microbiology, Faculty of Agriculture, Universitas Gadjah Mada, Yogyakarta, Indonesia, Jl. Flora, Bulaksumur, Sleman, Yogyakarta, 55281, email : wedhastri@faperta.ugm.ac.id morphology, colony's morphology, cell's biochemical properties, their ability to form root nodules (cross inoculation group) and nitrogen fixation (Boncher, 2009; De Bruijn 1992). Although phenotypic characterization is helpful in the identification of soil rhizobia diversity, the identification based on the molecular approaches believed to be more accurate (Naz et al., 2009). One of the molecular techniques that can be used to quickly identify the microbial diversity is by using Repetitive Extragenic Palindromic Polymerase Chain Reaction (REP-PCR) (Beyer et al., 1998). Diversity of LegumeNodulating Bacteria in the soil is affected by biotic factors such as cross inoculation group and abiotic factors such as land management (Madigan et al., 2003; Purwaningsih, 2009).

\section{Materials and Methods \\ Bacterial isolates}

USDA122, Tha7, and eleven LNB were isolated from several agroecosystems in Sumberjaya, Lampung which include 
UGM4, UGM5, UGM15, UGM19, UGM20, UGM22, UGM26, UGM27, UGM28, UGM35 and UGM39. These isolates are collections of Agricultural Microbiology Laboratory, Faculty of Agriculture, Universitas Gadjah Mada in Yogyakarta.

Phenotypic Characterization of LegumeNodulating Bacteria (LNB)

\section{Cells and colony's morphology}

Characterization of cell morphology include Gram properties, shape and size of the cells, and cell's motility. Bacterial culture in Yeast Mannitol Broth (YMB) (24-48 h) were used for testing Gram staining, shape and size of cells. Cell's motility was examined by using cultures that were grown on semi solid Yeast Mannitol Agar (YMA). Colony's morphology was examined by using cultures that were grown for $24-48 \mathrm{~h}$ on YMA.

\section{Cell's biochemical properties}

Biochemical properties were examined by testing isolates growth in several media, namely: Congo Red Yeast Mannitol Agar (CRYMA), Bromothymol Blue Yeast Mannitol Agar (BBYMA), and Glucose Pepton Agar (GPA). Bacterial isolates were also tested in the formation of 3-ketolactose, catalase activity, and the use of multiple sources of $\mathrm{C}$ and $\mathrm{N}$.

\section{Root nodulation (cross inoculation group) and nitrogen fixation test}

To test the ability in root nodulation, the eleven legume-nodulating bacteria isolates were used to inoculate several plants host. The plant hosts used in this work were: siratro (Macroptilium artropurpureum DC.), soybean (Glycine max L.), red bean (Vigna angularis), lamtoro (Leucaena leucocephala) and sengon (Albizzia falcataria) using minirhizotron method (made from disposable petridish) (Figure 1).

The ability of nitrogen fixation was examined by using Acetylene Reduction Assay (ARA) (Halbleib and Ludden, 2000).

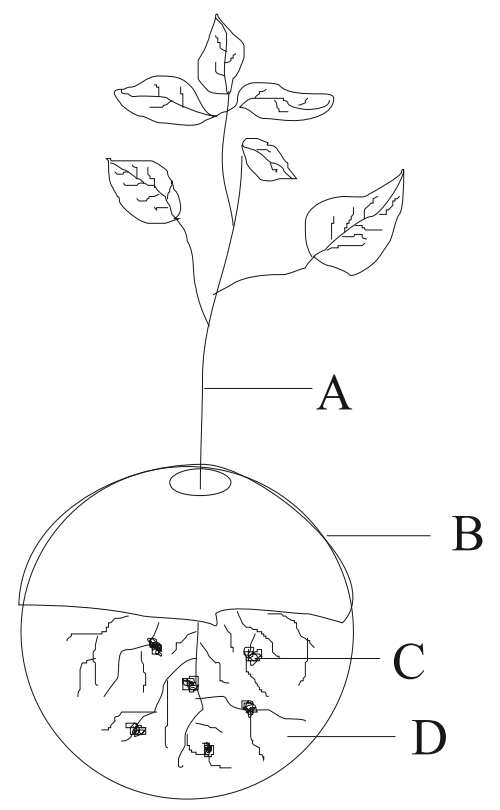

Figure 1. Plant growth scheme with minirhizotron methods A) plants B) Dispossable petridish covered with aluminum foil, $\mathrm{C}$ ) root nodules, and D) zeolite

\section{Genotypic characterization of Legume- Nodulating Bacteria (LNB).}

\section{DNA isolation.}

$1,5 \mathrm{ml}$ bacterial culture in Nutrient Broth (NB) medium (18-24 h) were transferred into microtube, then centrifuged at $12,000 \mathrm{rpm}$ for $5 \mathrm{~min}$. Supernatant was then discarded and the pellets were dissolved with $410 \mu \mathrm{TE}(10 \mathrm{mM}$ Tris-HCl; 1mM EDTA ( $\mathrm{pH}$ 8) supplemented with $50 \mu$ lysosim $(60 \mathrm{mg} / \mathrm{ml})$ and incubated at $37^{\circ} \mathrm{C}$ for $30 \mathrm{~min}$. The solution was added with $30 \mu \mathrm{l}$ SDS 10\% (10 gram in $100 \mathrm{ml}$ sterile distilled water) and $10 \mu \mathrm{l}$ proteinase-K (20 $\mathrm{mg} / \mathrm{ml}$ ) and incubated at $37^{\circ} \mathrm{C}$ for $30 \mathrm{~min}$. It was coupled with $100 \mu \mathrm{l} \mathrm{NaCl} 5 \mathrm{M}$ and $200 \mu \mathrm{l}$ solution CTAB $10 \%$ in $\mathrm{NaCl}$, then incubated at $65{ }^{\circ} \mathrm{C}$ for $10-15 \mathrm{~min}$. After incubation, 600 $\mu l$ chloroform was added and homogenized, then centrifuged at $12.000 \mathrm{rpm}$ for $5 \mathrm{~min}$. It resulted in a solution with 3 layers. Then the top layer was transferred into new microtubes and isopropanol was added to $500 \mu \mathrm{l}$. The mixture was then incubated for $24 \mathrm{~h}$ in the refrigerator and centrifuged again at 12,000 rpm for $5 \mathrm{~min}$. Supernatant was discarded and the pellet 
was washed with $100 \mathrm{ml}$ 70\% ethanol and centrifuged at 12,000 rpm for $5 \mathrm{~min}$ and then air dried for over night and redissolved with 50 $\mathrm{ml}$ TE buffer solution. The purity of genomic DNA were examined by electrophoresis on $1 \%$ Agarose.

\section{REP-PCR.}

The reaction mixture contained $1 \mu \mathrm{lDNA}$ genome, $12.5 \mu \mathrm{l}$ KAPPA PCR kit, $9 \mu$ nuclease free water and $2.5 \mu \mathrm{l}$ primer BOX AIR (5'-CTAC GGCAAGGCAAGGCGACGCTGACGCTGA (G-3'), so the total reaction volume was $25 \mathrm{ml}$. The reaction mix was placed on a termocycler and subjected to PCR cycles: $95^{\circ} \mathrm{C}$ for $4 \mathrm{~min}$., followed by 30 cycles of $94^{\circ} \mathrm{C}$ for $30 \mathrm{sec}, 51^{\circ} \mathrm{C}$ for $1 \mathrm{~min}$. and $65^{\circ} \mathrm{C}$ for $8 \mathrm{~min}$, and followed by the final elongation at $65^{\circ} \mathrm{C}$ for $8 \mathrm{~min}$. PCR amplified fragments were electrophoresed in an agarose gel (1.5\%) for $50 \mathrm{~min}$. and were visualized using ethidium bromide staining.

\section{Result and Discussion}

Phenotypic characterization of Legume Nodulating Bacteria (LNB)

Phenotypic characterization of rhizobia was performed by identifying the colony morphology, cell morphology, Gram properties, biochemical properties of cells (Boncher, 2009) and examination of crossinoculation group bacteria (De Bruijn, 1992). Rhizobium is a Gram-negative, rod-shaped, aerobic, motile and does not form spores. Colonies usually white or cream with circulair shape, convex, semi-transculent or dark and low convex with diameter $2-4 \mathrm{~mm}$ at the age of 3-5 days in medium Yeast Mannitol Agar (YMA). The genus Rhizobium bacteria grow at optimum temperature of $25-30{ }^{\circ} \mathrm{C}$ at $\mathrm{pH}$ 6-7. Almost all bacteria of the genus Rhizobium are able to form root nodules on legume whether or not they perform nitrogen fixation (Kuykendall et al., 1889).

Table 1. The observation of colony and cell morphology

\begin{tabular}{|c|c|c|c|c|c|c|c|c|c|c|}
\hline \multirow[b]{2}{*}{ No } & \multicolumn{6}{|c|}{ Colony's morphology } & \multicolumn{4}{|c|}{ Cell's morphology } \\
\hline & Isolate & $\begin{array}{l}\text { Shape of } \\
\text { colony }\end{array}$ & $\begin{array}{c}\text { Ele- } \\
\text { vation }\end{array}$ & $\begin{array}{l}\text { The edge } \\
\text { of the } \\
\text { colony }\end{array}$ & $\begin{array}{c}\text { The } \\
\text { structure of } \\
\text { the colony }\end{array}$ & $\begin{array}{l}\text { Colony } \\
\text { growth on } \\
\text { CRYMA }\end{array}$ & $\begin{array}{c}\text { Shape } \\
\text { of the } \\
\text { cell }\end{array}$ & Gram & $\begin{array}{l}\text { Size of the cell } \\
\qquad(\mu \mathrm{m})\end{array}$ & Motility \\
\hline 1 & USDA122 & Circulair & $\begin{array}{c}\text { Low } \\
\text { convex }\end{array}$ & Undulate & $\begin{array}{l}\text { Coarsely } \\
\text { Grannular }\end{array}$ & red & Rod & negative & $0,5 \times 0,7-3,1$ & Motile \\
\hline 2 & THA7 & Irregulair & $\begin{array}{c}\text { Low } \\
\text { convex }\end{array}$ & Undulate & $\begin{array}{l}\text { Finely } \\
\text { Grannular }\end{array}$ & white & Rod & negative & $0,5 \times 1,05-4,2$ & Motile \\
\hline 3 & UGM4 & Amoeboid & $\begin{array}{c}\text { Low } \\
\text { convex }\end{array}$ & Lobate & $\begin{array}{l}\text { Finely } \\
\text { Grannular }\end{array}$ & red & Rod & negative & $0,35-0,5 \times 1,05-2,1$ & $\begin{array}{c}\text { No } \\
\text { Motile }\end{array}$ \\
\hline 4 & UGM5 & Circulair & $\begin{array}{l}\text { Low } \\
\text { convex }\end{array}$ & Undulate & $\begin{array}{l}\text { Finely } \\
\text { Grannular }\end{array}$ & white & Rod & negative & $0,5 \times 0,7-3,1$ & $\begin{array}{c}\text { No } \\
\text { Motile }\end{array}$ \\
\hline 5 & UGM15 & Circulair & $\begin{array}{l}\text { Low } \\
\text { convex }\end{array}$ & Entire & $\begin{array}{c}\text { Finely } \\
\text { Grannular }\end{array}$ & $\begin{array}{l}\text { white- } \\
\text { yellowish }\end{array}$ & Rod & negative & $0,5 \times 0,7-3,1$ & $\begin{array}{c}\text { No } \\
\text { Motile }\end{array}$ \\
\hline 6 & UGM19 & Amoeboid & Effuse & Ramose & $\begin{array}{c}\text { Wavy } \\
\text { Entelaced }\end{array}$ & red & Rod & negative & $0,525-0,7 \times 1,05-3,1$ & Motile \\
\hline 7 & UGM22 & Circulair & $\begin{array}{l}\text { Low } \\
\text { convex }\end{array}$ & Entire & $\begin{array}{l}\text { Finely } \\
\text { Grannular }\end{array}$ & white & Coccus & negative & $0,5 \times 0,5$ & $\begin{array}{c}\text { No } \\
\text { Motile }\end{array}$ \\
\hline 8 & UGM26 & Cirulair & $\begin{array}{c}\text { Low } \\
\text { convex }\end{array}$ & Undulate & $\begin{array}{l}\text { Coarsely } \\
\text { Grannular }\end{array}$ & pink & Rod & negative & $1,05 \times 2,1-3,1$ & $\begin{array}{c}\text { No } \\
\text { Motile }\end{array}$ \\
\hline 9 & UGM27 & Circulair & Effuse & Undulate & $\begin{array}{l}\text { Finely } \\
\text { Grannular }\end{array}$ & white & Rod & negative & $0,5-1,05 \times 1,05-2,1$ & $\begin{array}{c}\text { No } \\
\text { Motile }\end{array}$ \\
\hline 10 & UGM28 & Circulair & $\begin{array}{c}\text { Low } \\
\text { convex }\end{array}$ & Entire & $\begin{array}{l}\text { Finely } \\
\text { Grannular }\end{array}$ & white & Coccus & negative & $0,5 \times 0,5$ & $\begin{array}{c}\text { No } \\
\text { Motile }\end{array}$ \\
\hline 11 & UGM35 & Circulair & $\begin{array}{c}\text { Low } \\
\text { convex }\end{array}$ & Undulate & $\begin{array}{l}\text { Coarsely } \\
\text { Granular }\end{array}$ & $\begin{array}{l}\text { white- } \\
\text { reddish }\end{array}$ & Rod & negative & $0,5-0,7 \times 0,7-3,1$ & $\begin{array}{c}\text { No } \\
\text { Motile }\end{array}$ \\
\hline 12 & UGM39 & Circulair & Effuse & Entire & $\begin{array}{l}\text { Coarsely } \\
\text { Granular }\end{array}$ & pink & Rod & negative & $0.5-1,05 \times 2,1-3,1$ & Motile \\
\hline 13 & UGM20 & Circulair & Effuse & Entire & $\begin{array}{c}\text { Finely } \\
\text { Grannular }\end{array}$ & red & Rod & negative & $0,5 \times 2,1-5,25$ & Motile \\
\hline
\end{tabular}




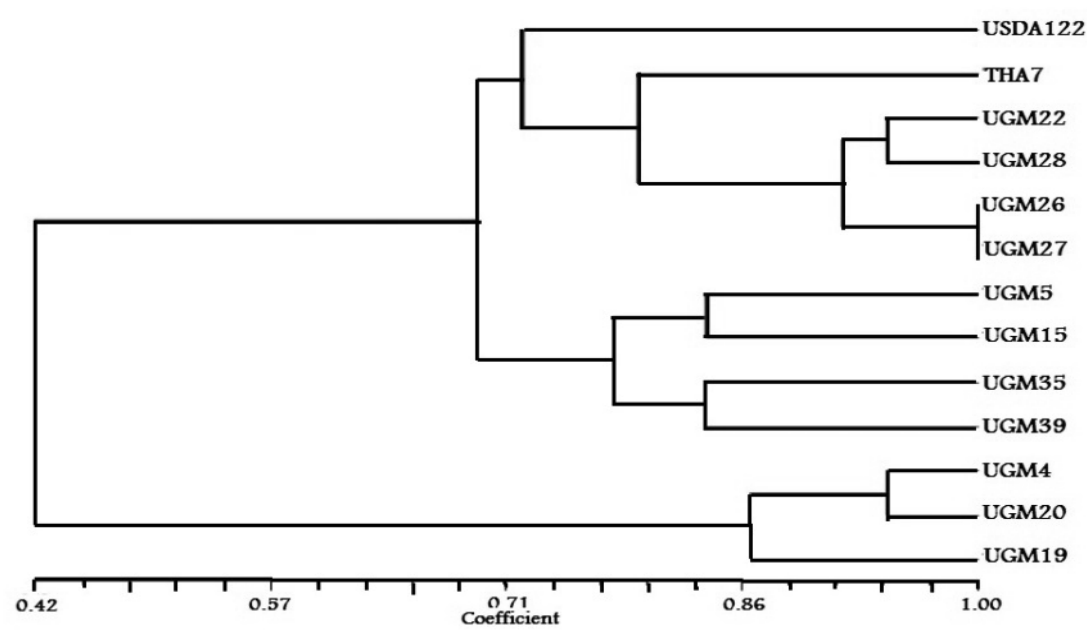

Figure 2. Dendogram of similarity relationship between tested isolates by biochemical tests

Table 2. Ability to form root nodules (cross inoculation group) test

\begin{tabular}{|c|c|c|c|c|c|c|}
\hline \multirow{2}{*}{ No } & \multirow{2}{*}{ Isolates } & \multicolumn{5}{|c|}{ The number of root nodules } \\
\hline & & Siratro & Soybean & Red Beans & Lamtoro & Sengon \\
\hline 1 & USDA122 & + & + & - & - & + \\
\hline 2 & THA7 & + & + & + & - & + \\
\hline 3 & UGM4 & + & + & - & - & + \\
\hline 4 & UGM5 & + & + & + & - & + \\
\hline 5 & UGM15 & + & + & - & - & + \\
\hline 6 & UGM19 & + & + & - & - & + \\
\hline 7 & UGM22 & + & + & - & - & + \\
\hline 8 & UGM26 & + & + & - & - & + \\
\hline 9 & UGM27 & + & + & - & - & + \\
\hline 10 & UGM28 & + & + & - & - & + \\
\hline 11 & UGM35 & + & + & - & - & + \\
\hline 12 & UGM39 & + & + & - & - & + \\
\hline 13 & UGM20 & + & + & - & - & + \\
\hline 14 & Kontrol (-) & - & - & - & - & - \\
\hline
\end{tabular}

Both morphological observations of the cells or colonies, indicating that overall the tested bacteria are Gram-negative bacteria to form colonies almost entirely circular and forms the majority of the cells are rod (Table 1).

Biochemical data indicated that all of bacterial isolates tested were from different groups (Figure 2). This was indicated by the low coefficient of similarity. Only isolates UGM26 and UGM27 that indicated a close relationship with similarity coefficient was
1. This indicates that the two isolates were from the same group.

Biochemical data indicated that there was a high diversity of bacterial isolates tested. Judging from the origin of the isolates tested, these isolates came from different agroecosystems. This proved that environmental factors, especially soil tillage systems and different types of crop diversity affect rhizobia in the soil. The evaluation on the ability of root nodule formation showed that there was low cross-inoculation group. 


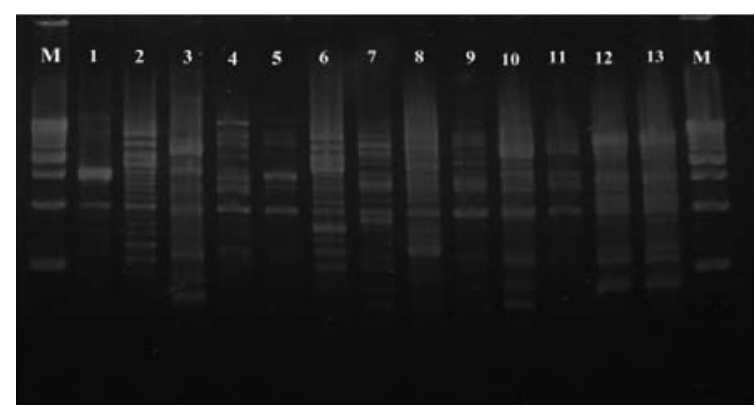

Figure 3. Amplificatin product of REP-PCR in agarose 1,5 \% (b/v). M = marker DNA; 1 = UGM4; 2 = UGM5; 3 = UGM15; 4 = UGM19; 5 = UGM22; 6 = UGM26; 7 = UGM27; 8 = UGM28; 9 = UGM35; 10 = UGM39; 11 = UGM20; 12 = USDA122; 13 = THA7

This was indicated by the uniformity of the results shown in the five plants used in testing (Table 2).

\section{Genotypic characterization of Legume- Nodulating Bacteria (LNB).}

REP-PCR can be used in the identification and classification of bacterial strains (De Bruijn 1992; Xue-Xian et al.,1999). Techniques Repetitive Extragenic Palindromic Polymerase Chain Reaction (REP-PCR) can be used to distinguish microbial diversity based on the number and spacing of its repetitive sequences. REP-PCR data indicated that eleven bacteria tested had a high diversity (Figure 3 and 4).

As the conclusion, the 11 isolates of Legume- Nodulating Bacteria tested had high phenotypic and genotypic diversity. There were two cross-inoculation group, namely: (1) UGM5 were able to form nodules on the plant siratro, soybeans, red beans and sengon, and (2) UGM4, UGM15, UGM19, GMU 22, UGM26, UGM27, UGM28, UGM35, UGM39 and UGM20 were able to form nodules on the plant siratro, soy and sengon.

\section{References}

Barcellos, F. G., Menna,P., da Silva Batista, J. S. and Hungria, M. 2007. Evidence of Horizontal Transfer of Symbiotic Genes from a Bradyrhizobium japonicum Inoculant Strain to Indigenous Diazotrophs Sinorhizobium (Ensifer) fredii and Bradyrhizobium elkanii in a Brazilian Savannah Soil. Appl. Env.Microbiol. 73,2635-2643.

Beyer, W., Mukendi, F.M.,. Kimmig, P., and Bohm, R. 1998. Suitability of RepetitiveDNA-Sequence-Based PCR Fingerprinting for Characterizing Epidemic Isolate of Salmonella enterica Serovar Saintpaul. J. Clin. Microbiol. 36, 1549 - 1554.

Boncher, B. R. 2009. Global phenotypic characterization of bacteria. Feder.Europ. Microbiol. Soc. Rev., 33, 191-205.

De Bruijn, 1992. Use of Repetitive (Repetitive Extragenic Palindromic and Enterobacterial Repetitive Intergeneric Consensus) Sequences and the Polymerase Chain Reaction To Fingerprint the Genomes of

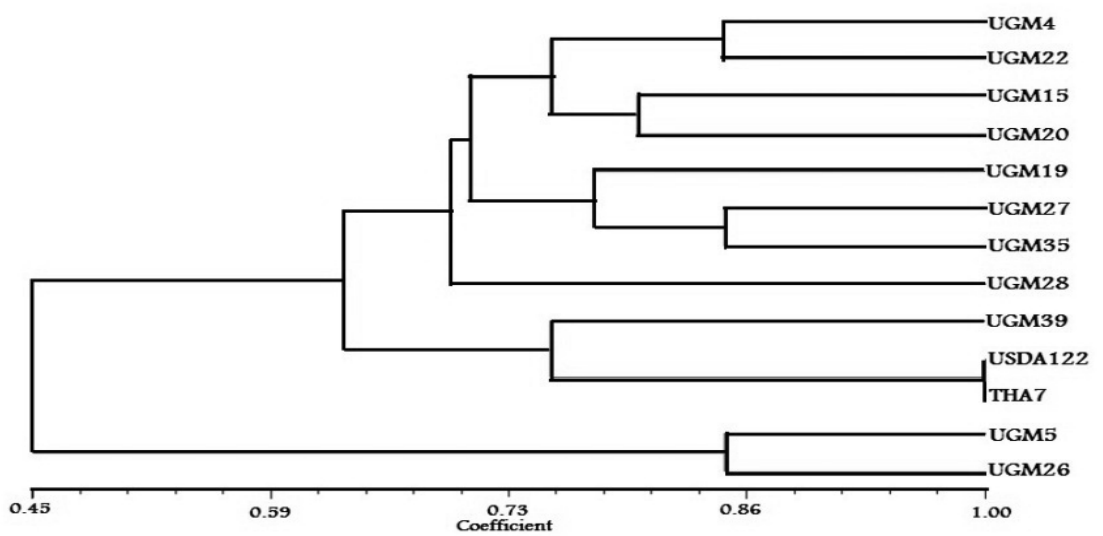

Figure 4. Dendogram of similarity relationship between test isolates by REP-PCR amplification results 
Rhizobium meliloti Isolates and Other Soil Bacteria. App.Env. Microbiol. 58, 21802187.

Halbleib, C. M. and Ludden, P.W. 2000. Regulation of Biological Nitrogen Fixation. American Society for Nutritional Science. J.Nutr., 130, 1081-104.

Kuykendall, L. D., Young, J.M.,MartinezRomero, E., Kerr, A. and Sawada, H. (1889). Genus Rhizobium. In: D. J. Brener, N. R. Krieg, J. T. Staley Bergey's Manual of Systematic Bacteriology Second Edition. Springer.

Madigan, M., Martinko, J.M., dan Parker, J. (2003). Brock: Biology of Microorganism. 10th Edition Pretince Hall. USA.

Mahdhi, M., Fterich, A., Rejili, M., RodriguezLlorente, I.D., and Mars, M. 2011. Legumenodulating bacteria (LNB) from three pasture legumes (Vicia sativa, Trigonella maritima and Hedysarum spinosissimum) in Tunisia. Ann. Microbiol. 62, 61-68.

Naz, I., Bano, A., and Ul-Hassan, T. 2009. Morphologycal, Biochemical and Molecular Caracterization of Rhizobia from Halophytes of Khewr Salt Range and Attock. Pakistan J. Botany, 41, 31593168.

Purwaningsih, S. 2009. Populasi Bakteri Rhizobium di Tanah pada Beberapa Tanaman dari Pulau Buton, Kabupaten Muna, Propinsi Sulawesi Tenggara. J. Tanah Trop. 14, 65-70.

Weir, B. S. 2012. The current taxonomy of rhizobia. <http://www.rhizobia.co.nz/ taxonomy/rhizobia>. Accessed on May 17, 2012.

Xue-Xian, Z., Muilenburg, M.,An Lie, T.Jun-Chu, Z., and Li Fu-Di. 1999. Characterization of Soybean Rhizobia at Different Levels Using PCR Based Techniques. Chin.Biodiv. 7, 277 - 284. 